\title{
Effect of Papulacandin B on the Cell Wall and Growth of Geotrichum lactis
}

\author{
By PILAR PÉREZ, ${ }^{1}$ ISABEL GARCÍA-ACHA ${ }^{2}$ AND ANGEL DURÁN 2* \\ ${ }^{1}$ Department of Microbiology, Faculty of Biology, University of Salamanca, Salamanca, Spain \\ ${ }^{2}$ Institute of Microbial Biochemistry, CSIC, Salamanca, Spain
}

(Received 25 March 1982; revised 29 April 1982)

\begin{abstract}
Addition of the antifungal antibiotic papulacandin B to an exponential culture of Geotrichum lactis inhibited incorporation of glucose into the alkali-insoluble and alkali-soluble glucan fractions of the hyphal wall, although the rate of growth was practically unaltered. Synthesis of other cell wall components (i.e. galactomannan and chitin) was not affected. Papulacandin B also induced the proliferation of branches along the hyphae which continued to branch dichotomously resulting in a 'colonial' pattern of growth. Aculeacin A, another antifungal antibiotic that inhibited $\beta$-glucan synthesis also caused morphological alterations similar to those described for papulacandin B. Inhibition of $\beta$-glucan synthesis and the altered growth pattern persisted for several hours after removal of the antibiotic. Recovery of $\beta$-glucan synthesis and restoration of the normal pattern of growth occurred simultaneously. Growth of $G$. lactis in $\mathrm{L}$-sorbose medium also led to inhibition of $\beta$-glucan synthesis and dichotomous branching.
\end{abstract}

\section{INTRODUCTION}

It has been proposed that the antifungal compounds papulacandin B and aculeacin A (Traxler et al., 1977; Mizuno et al., 1977) interfere with cell wall synthesis in yeasts since glucose incorporation into the alkali-insoluble glucan fraction of the cell wall of Saccharomyces cerevisiae is inhibited by these antibiotics (Baguley et al., 1979; Mizoguchi et al., 1977). Recently we have established that papulacandin B and aculeacin A specifically inhibit the 1,3- $\beta$-glucan synthesis of Geotrichum lactis in vitro (Pérez et al., 1981).

The experiments reported in this paper describe the in vivo effect of papulacandin B, aculeacin $A$ and L-sorbose on the growth of $G$. lactis. The main parameter measured was $\beta$-glucan synthesis defined either as glucose incorporation into cell wall glucan by intact hyphae or as $1,3-\beta$-glucan synthase activity levels in cell-free extracts of the fungus.

\section{METHODS}

Chemicals. Papulacandin B and aculeacin A were generous gifts of CIBA-Geigy and the Toyo-Jozo Co., Tokyo, Japan, respectively. UDP-[U-14 C]glucose $\left(240 \mathrm{mCi} \mathrm{mmol}^{-1}\right)$, UDP-[U-14 $\left.\mathrm{C}\right] N$-acetylglucosamine $(346 \mathrm{mCi}$ $\left.\mathrm{mmol}^{-1}\right)$, [U-14 $\mathrm{C}$ glucose $\left(295 \mathrm{mCi} \mathrm{mmol}^{-1}\right)$, $\left[2{ }^{-14} \mathrm{C}\right]$ uracil $\left(60 \mathrm{mCi} \mathrm{mmol}^{-1}\right.$; where $\left.1 \mathrm{mCi}=37 \mathrm{MBq}\right)$ and ${ }^{3} \mathrm{H}-$ labelled amino acid mixture were purchased from Amersham. UDP-glucose, UDP- $N$-acetylglucosamine and GTP were purchased from Sigma. Chitinase from Streptomyces griseus (ATCC 23345) was purified by adsorption to chitin as described previously (Molano et al., 1977) and zymolyase-5000 was obtained from Kirin Brewery Co., Tokyo, Japan. L-Sorbose and cellobiose were obtained from Merck.

Culture conditions. Geotrichum lactis CECT 1102 (Colección Española de Cultivos Tipo) was grown in YED

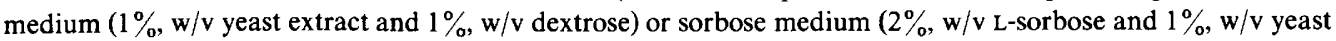
extract) as described previously (Pérez et al., 1981). Growth was monitored by measuring the dry weight of mycelium harvested by filtration of cultures through Whatman no. 1 filter paper.

Determination of protein and RNA synthesis. Protein and RNA synthesis as well as glucose incorporation were monitored by measuring the radioactivity in TCA-insoluble material (Santos et al., 1978) from cultures supplemented with $\left[2-{ }^{14} \mathrm{C}\right]$ uracil $\left(0 \cdot 2 \mu \mathrm{Ci} \mathrm{ml}^{-1}\right),{ }^{3} \mathrm{H}$-labelled amino acids $\left.(4 \mu \mathrm{Ci} \mathrm{ml})^{-1}\right)$ or $\left[\mathrm{U}-{ }^{14} \mathrm{C}\right]$ glucose $\left(0 \cdot 2 \mu \mathrm{Ci} \mathrm{ml}{ }^{-1}\right.$; where $\left.1 \mu \mathrm{Ci}=37 \mathrm{kBq}\right)$, respectively. 
Labelling and fractionation of cell wall polysaccharides. An exponential phase culture of $G$. lactis was harvested and the mycelium resuspended at a concentration of about $1 \mathrm{mg} \mathrm{dry} \mathrm{wt} \mathrm{ml}^{-1}$ in fresh YED medium supplemented with $\mathrm{D}-\left[\mathrm{U}^{-14} \mathrm{C}\right] \mathrm{glucose}\left(0.4 \mu \mathrm{Ci} \mathrm{ml}^{-1}\right)$. Samples were taken at appropriate time intervals and carrier mycelium $(1 \mathrm{~g}$ wet wt) was added to the radioactive samples and then submitted to mechanical breakage as previously described (Pérez et al., 1981). Cell walls were washed with water by centrifugation at $750 \mathrm{~g}$ for 5 min several times and then extracted twice with $5 \mathrm{ml} 6 \%(\mathrm{w} / \mathrm{v}) \mathrm{NaOH}$ for $90 \mathrm{~min}$ at $80^{\circ} \mathrm{C}$. The precipitation of galactomannan from the extract with Fehling reagent was performed as described by Algranati et al. (1966). Alkali-soluble glucan and galactomannan were precipitated together by addition of 2 vol. absolute ethanol to the alkali extract. The difference between the counts obtained in the ethanol-precipitated pellet and that produced by the Fehling reagent was taken to represent alkali-soluble glucan. Previous experiments showed that no glycogen was present in any fraction. The residue remaining after $\mathrm{NaOH}$ extraction was washed by centrifugation until the $\mathrm{pH}$ was neutral and resuspended in $1.5 \mathrm{ml}$ water. Samples of $0.4 \mathrm{ml}$ were incubated for $48 \mathrm{~h}$ at $30^{\circ} \mathrm{C}$ with 60 milliunits of chitinase (one milliunit is defined as the amount of enzyme that releases $1 \mathrm{nmol} N$-acetylglucosamine equivalents $\min ^{-1}$ at $30^{\circ} \mathrm{C}$ ) or $100 \mu \mathrm{g}$ zymolyase in $50 \mathrm{~mm}$-phosphate buffer at $\mathrm{pH} 6.3$, in a final volume of $0.5 \mathrm{ml}$. A sample without enzyme was always included as a control. After incubation the samples were centrifuged, washed and counted. The residues produced after digestion with chitinase or zymolyase were taken to represent alkali-insoluble glucan or chitin, respectively.

Other methods. Radioactivity in insoluble samples was determined with a scintillation mixture containing a thixotropic gel (Keller \& Cabib, 1971) using a Beckman LS-8100 scintillation counter. Cell-free extracts were obtained as in Pérez et al. (1981). Chitin and glucan synthase activities were assayed and determined essentially as previously described (Durán \& Cabib, 1978; Shematek et al., 1980). Protein was measured by the Lowry method. The morphology of the fungus was monitored in a Leitz phase-contrast microscope.

\section{RESULTS}

\section{Effect of papulacandin $B$ on fungal growth}

Addition of papulacandin $B$ at sub-lethal concentrations (i.e. $6 \mu \mathrm{g} \mathrm{ml}^{-1}$ ) to an exponential phase culture of $G$. lactis resulted in a reduction of the extension rate and the appearance of protuberances along the hyphae (Fig. $1 a$ ) that continued to grow and branch dichotomously at least four to five times (Fig. $1 b$ ). By contrast, branches in the control cultures were not as frequent and appeared almost exclusively behind septa, never at the tips (Fig. $1 c$; Fiddy \& Trinci, 1976). Similar morphological alterations were produced by aculeacin A (Fig. $1 d$ ), another antifungal antibiotic that inhibits 1,3- $\beta$-glucan synthase in $G$. lactis (Pérez et al., 1981). These morphological changes, however, did not alter growth excessively. Thus, after culturing for $6 \mathrm{~h}$ in the presence of 6,10 and $30 \mu \mathrm{g}$ antibiotic $\mathrm{ml}^{-1}$, yields of $4.3,4.2$ and $3.4 \mathrm{mg}$ dry wt $\mathrm{ml}^{-1}$, respectively, were obtained as compared to $4.5 \mathrm{mg}$ dry wt $\mathrm{ml}^{-1}$ in the control (without antibiotic).

The incorporation of uracil and amino acids from cultures supplemented with $6 \mu \mathrm{g}$ papulacandin $B \mathrm{ml}^{-1}$ reached values similar to those of the control while incorporation of glucose was slightly inhibited (Fig. 2). Concentrations of antibiotic higher than $60 \mu \mathrm{g} \mathrm{ml}^{-1}$ resulted in considerable lysis of the mycelium and a substantial decrease in growth (results not shown).

\section{Effect of papulacandin $B$ on synthesis of cell wall polysaccharides}

It was important to ascertain whether the action of papulacandin $B$ would specifically affect $\beta$-glucan synthesis in vivo. Papulacandin $\mathrm{B}\left(6 \mu \mathrm{g} \mathrm{ml}^{-1}\right)$ was added to a growing culture of $G$. lactis followed $30 \mathrm{~min}$ later by the addition of $\left[{ }^{14} \mathrm{C}\right]$ glucose. Incorporation of label into the galactomannan and chitin fractions of antibiotic-treated mycelium was unaffected, whereas incorporation into the glucan fractions (both alkali-insoluble and alkali-soluble) was reduced by $76 \%$ and $47 \%$, respectively (Table 1 ). Similar results were obtained in two additional independent experiments.

\section{Cell wall synthase activity levels and growth pattern of mycelium derived from papulacandin $B$ treated arthrospores}

Suspensions of arthrospores in YED medium $\left(4 \times 10^{6}\right.$ cells $\left.\mathrm{ml}^{-1}\right)$ were incubated in the presence of papulacandin $\mathrm{B}\left(10 \mu \mathrm{g} \mathrm{ml}^{-1}\right)$ at $30^{\circ} \mathrm{C}$. After $90 \mathrm{~min}$ the arthrospores were washed twice and used as inocula for $500 \mathrm{ml}$ flasks containing $125 \mathrm{ml}$ YED medium. Cultures were 

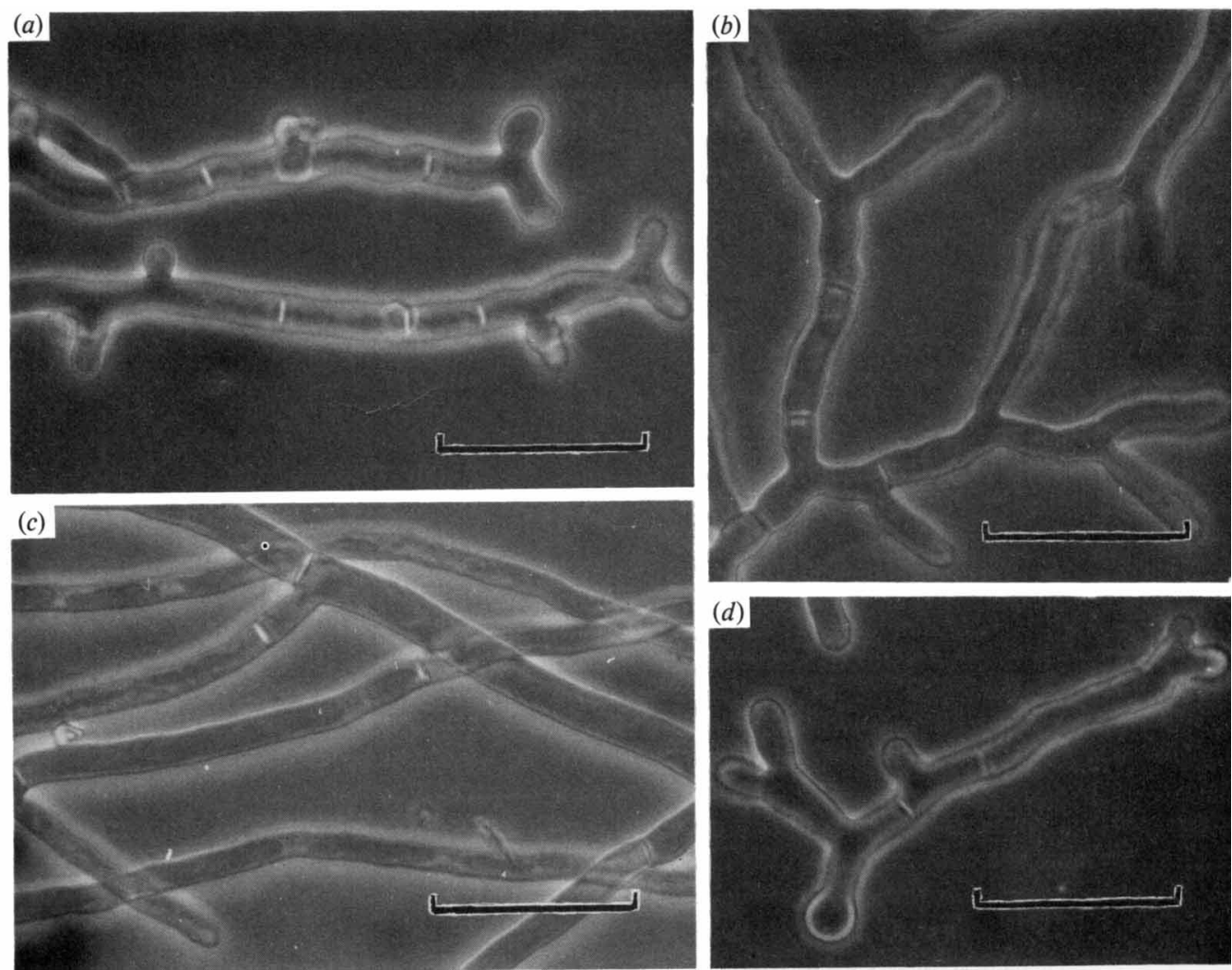

Fig. 1. Phase-contrast micrographs of $G$. lactis mycelium grown in the presence of papulacandin B $(6 \mu \mathrm{g}$ $\mathrm{ml}^{-1}$ ) or aculeacin A $\left(18 \mu \mathrm{g} \mathrm{ml}^{-1}\right)$. (a) Protuberances along the hyphae after papulacandin $\mathrm{B}$ treatment. (b) Dichotomous branching of mycelium after papulacandin B treatment. (c) Control culture without antibiotic. (d) Mycelium grown in the presence of aculeacin A. The bar markers represent $10 \mu \mathrm{m}$.

harvested after 6,12 and $18 \mathrm{~h}$ and cell wall synthase activities determined. The activities of 1,3$\beta$-glucan synthase in cell-free extracts from 6 and $12 \mathrm{~h}$ cultures of papulacandin B-treated arthrospores were $43 \%$ and $63 \%$ of the control values, respectively, whereas that of $18 \mathrm{~h}$ cultures was not inhibited (Table 2). Chitin synthase activity remained essentially unaltered in every case. Mycelium from 6 and $12 \mathrm{~h}$ cultures exhibited dichotomous branching at the tips; however, the branching pattern in $18 \mathrm{~h}$ mycelium was similar to that observed in the control. Samples from $12 \mathrm{~h}$ cultures were resuspended in fresh YED medium supplemented with $\left[{ }^{14} \mathrm{C}\right]$ glucose and incorporation of label into cell wall fractions was measured after 45 and 90 min of growth. Incorporation into glucan fractions from pre-treated arthrospores was $63 \%$ for the alkaliinsoluble glucan and $68 \%$ for the alkali-soluble glucan as compared to the control, whereas incorporation into galactomannan and chitin was similar in both treated and untreated cultures (data not shown).

\section{Effect of L-sorbose on the 1,3- $\beta$-glucan synthase and growth of $G$. lactis}

Although sorbose medium induced 'colonial' growth (as described by de Terra \& Tatum, $1961)$ in $G$. lactis, the addition of L-sorbose $(26 \mathrm{mM})$ to the $1,3-\beta$-glucan synthase assay system only resulted in a slight inhibition of the activity (data not shown). However, cell-free extracts from $G$. lactis grown in sorbose medium showed a reduced level of 1,3- $\beta$-glucan synthase activity as compared with that from cultures grown in YED medium; the chitin synthase value was even higher than the one detected in YED medium (Table 3). These values were obtained from exponential cultures with doubling times in YED and sorbose medium of 1.55 and $1.70 \mathrm{~h}$, 


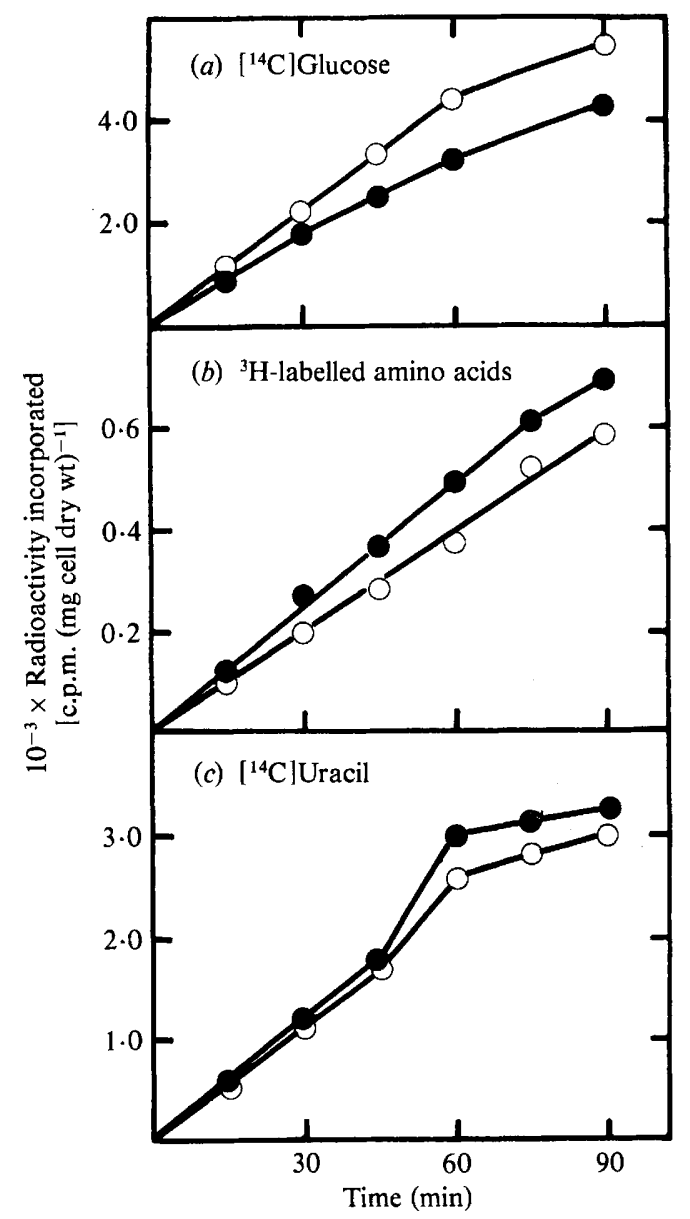

Fig. 2. Effect of papulacandin B on (a) glucose incorporation, (b) protein synthesis and (c) RNA synthesis in $G$. lactis. $\bigcirc$, Control; $\bigcirc$, treated with papulacandin B $\left(6 \mu \mathrm{g} \mathrm{ml}^{-1}\right)$.

Table 1. Effect of papulacandin $B$ on the incorporation of the radioactivity from $\left[{ }^{14} \mathrm{Clglucose}\right.$ into cell wall polysaccharides

Papulacandin B was added at a concentration of $6 \mu \mathrm{g} \mathrm{ml}^{-1}$. Figures in parentheses are percentages of control values.

Cell wall fraction

Alkali-insoluble glucan

Alkali-soluble glucan

Chitin

Galactomannan $\left[{ }^{14} \mathrm{C}\right]$ Glucose incorporated [c.p.m. (mg cell dry wt) $\left.{ }^{-1}\right]$

\begin{tabular}{|c|c|c|c|}
\hline \multicolumn{2}{|c|}{ Control } & \multicolumn{2}{|c|}{ Plus papulacandin B } \\
\hline $60 \mathrm{~min}$ & $120 \mathrm{~min}$ & $60 \mathrm{~min}$ & $120 \mathrm{~min}$ \\
\hline $\begin{array}{l}928 \\
558\end{array}$ & $\begin{array}{r}1536 \\
765\end{array}$ & $\begin{array}{l}161(17 \%) \\
400(72 \%\end{array}$ & $\begin{array}{l}372(24 \%) \\
402(53 \%)\end{array}$ \\
\hline 1315 & 1857 & 1502 & 1821 \\
\hline 705 & 1247 & 668 & 1279 \\
\hline
\end{tabular}

respectively. 1,3- $\beta$-Glucan synthase activity from sorbose cultures was inhibited in vitro by papulacandin B to a similar extent as that in YED medium cultures (Table 3). Cellobiose, another inducer of 'colonial' growth in several fungi (Wilson, 1970), and other L-sugars were neither inhibitors of the synthase nor inducers of morphogenic effects in G. lactis (results not shown). 
Table 2. Cell wall synthase activity of $G$. lactis mycelium grown from arthrospores pretreated with papulacandin $B$

Geotrichum lactis arthrospores were treated with papulacandin B $\left(10 \mu \mathrm{g} \mathrm{ml}^{-1}\right)$. After $90 \mathrm{~min}$ the arthrospores were washed and used as inoculum. Samples of mycelium were harvested at appropriate times and the synthase activities measured in the corresponding particulate fraction. The values presented are means from two experiments.

\begin{tabular}{|c|c|c|c|c|}
\hline \multirow[b]{2}{*}{ Enzyme } & \multirow[b]{2}{*}{ Treatment } & \multicolumn{3}{|c|}{$\begin{array}{c}\text { Specific activity } \\
{\left[\text { milliunits }(\mathrm{mg} \text { protein })^{-1}\right]^{*}}\end{array}$} \\
\hline & & $6 \mathrm{~h}$ & $12 \mathrm{~h}$ & $18 \mathrm{~h}$ \\
\hline $1,3-\beta$-Glucan synthase & $\left\{\begin{array}{l}\text { Control } \\
\text { Papulacandin B }\end{array}\right.$ & $\begin{array}{l}2 \cdot 1 \\
0 \cdot 9\end{array}$ & $\begin{array}{l}2 \cdot 7 \\
1 \cdot 7\end{array}$ & $\begin{array}{l}3 \cdot 3 \\
3 \cdot 3\end{array}$ \\
\hline Chitin synthase & $\left\{\begin{array}{l}\text { Control } \\
\text { Papulacandin B }\end{array}\right.$ & $\begin{array}{r}10 \cdot 2 \\
8 \cdot 7\end{array}$ & $\begin{array}{l}8 \cdot 0 \\
8 \cdot 1\end{array}$ & $\begin{array}{l}7 \cdot 1 \\
7 \cdot 3\end{array}$ \\
\hline
\end{tabular}

* One milliunit is defined as the amount of enzyme that incorporates $1 \mathrm{nmol}$ substrate min $^{-1}$ into product.

Table 3. Cell wall synthase activity of $G$. lactis grown in glucose or L-sorbose medium, and its inhibition by papulacandin $B$

\begin{abstract}
Growth medium contained $1 \%(w / v)$ yeast extract and $2 \%(w / v)$ of the corresponding sugar. The final concentration of papulacandin in the in vitro assay was $18 \mu \mathrm{M}$. The values presented are the means and standard deviations calculated from four independent experiments.
\end{abstract}

\begin{tabular}{|c|c|c|c|}
\hline \multirow[b]{2}{*}{$\begin{array}{l}\text { Growth } \\
\text { medium }\end{array}$} & \multicolumn{2}{|c|}{$\begin{array}{l}\text { 1,3- } \beta \text {-Glucan synthase } \\
\text { activity [milliunits } \\
\left.\text { (mg protein })^{-1}\right]^{*}\end{array}$} & \multirow{2}{*}{$\begin{array}{l}\text { Chitin synthase } \\
\text { activity [milliunits } \\
\left.(\mathrm{mg} \text { protein })^{-1}\right]^{*}\end{array}$} \\
\hline & Control & $\begin{array}{c}\text { Plus } \\
\text { Papulacandin B }\end{array}$ & \\
\hline $\begin{array}{l}\text { Glucose } \\
\text { L-Sorbose }\end{array}$ & $\begin{array}{l}3.4 \pm 0.29 \\
2.0 \pm 0.21\end{array}$ & $\begin{array}{l}1.0 \pm 0.10 \\
0.6 \pm 0.07\end{array}$ & $\begin{array}{l}6 \cdot 8 \pm 1 \cdot 0 \\
8 \cdot 5 \pm 1 \cdot 1\end{array}$ \\
\hline
\end{tabular}

* For definition of milliunits see footnote to Table 2 .

\title{
DISCUSSION
}

Analysis of cell wall components of $G$. lactis grown in the presence of papulacandin B clearly indicates that synthesis of $\beta$-glucan is partially inhibited. Under these conditions RNA and protein synthesis is slightly greater than in control cultures while growth yields, after $6 \mathrm{~h}$ of growth and even longer, are almost identical (results not shown). Therefore it seems that growth is not significantly altered.

Parallel to the inhibition of $\beta$-glucan synthesis, papulacandin B induces branch proliferation and 'colonial' growth. Aculeacin A, another antifungal antibiotic that specifically inhibits $1,3-\beta$ glucan synthase in G. lactis (Pérez et al., 1981) also induces morphological alterations similar to the ones described for papulacandin B. Likewise, L-sorbose, a known inducer of morphological effects in Neurospora crassa (Mishra \& Tatum, 1972), reduces the 1,3- $\beta$-glucan synthase activity levels of $G$. lactis in vivo and induces 'colonial' growth. On the other hand the results in Table 2 indicate that inhibition of $\beta$-glucan synthesis still persists for up to several hours after removal of the antibiotic. Recovery of $\beta$-glucan synthesis and restoration of a morphologically normal pattern of growth seems to occur simultaneously. This recovery is not explained by the development of resistance to the antibiotic as the fungus remains sensitive to further additions of papulacandin B. The data presented suggest that inhibition of $\beta$-glucan synthesis and 'colonial' growth in G. lactis may be correlated. A rationale for this correlation is suggested. Trinci (1979) has proposed a hypothesis to account for the regulation of branch initiation in fungi. According to this, apical branching as well as lateral branching in the absence of septation may occur when the rate of supply of components required for primary wall growth (i.e. vesicles, wall precursors 
and enzymes which synthesize or lyse wall polymers) exceeds the rate at which they can be incorporated into the tip wall. Papulacandin B, by inhibiting 1,3- $\beta$-glucan synthesis, would reduce the rate of incorporation of this material into the wall ( $\beta$-glucan is quantitatively and qualitatively an important structural component). This unbalanced situation with a relative excess of hydrolytic enzymes (i.e. $\beta$-glucanases) would weaken the wall and consequently branching would occur mainly at the tip and also along the hypha. The reason why branches are initiated at precise locations has yet to be understood.

It may be relevant to mention that growth of Schizosaccharomyces pombe in the presence of aculeacin A induces swelling of the cells at the growing pole (Miyata et al., 1980) and that papulacandin B induces both inhibition of $1,3-\beta$-glucan synthesis in vivo, and an identical morphological effect (R. Varona \& A. Durán, unpublished results).

This work was supported by a grant from the Comisión Asesora de Investigación Científica y Técnica and by a grant from the Fondo de Investigaciones Sanitarias. P. P. acknowledges the support from a fellowship granted by the Ministerio de Universidades e Investigación, Spain.

\section{REFERENCES}

Algranati, I. D., Behrens, N., Carminatti, H. \& CABIB, E. (1966). Mannan synthetase from yeast. Methods in Enzymology 8, 411-416.

Baguley, B. C., Rommele, G., Gruner, J. \& WeHRl, W. (1979). Papulacandin B: an inhibitor of glucan synthesis in yeast sphaeroplasts. European Journal of Biochemistry 97, 345-351.

de Terra, N. \& Tatum, E. L. (1961). Colonial growth of Neurospora. Science 134, 1066-1068.

Durán, A. \& CABIB, E. (1978). Solubilization and partial purification of yeast chitin synthase. Confirmation of the zymogenic nature of the enzyme. Journal of Biological Chemistry 253, 4419 4425.

Fiddy, C. \& TrincI, A. P. J. (1976). Nuclei, septation, branching and growth of Geotrichum candidum. Journal of General Microbiology 97, 185-192.

Keller, F. A. \& CABIB, E. (1971). Chitin and yeast budding. Properties of chitin synthetase from Saccharomyces carlsbergensis. Journal of Biological Chemistry 246, 160-166.

Mishra, N. C. \& Tatum, E. L. (1972). Effect of Lsorbose on polysaccharide synthetase of Neurospora crassa. Proceedings of the National Academy of Sciences of the United States of America 69, 313-317.

MiYata, M., Kitamura, J. \& MiYata, H. (1980). Lysis of growing fissing-yeast cells induced by Aculeacin A, a new antifungal antibiotic. Archives of Microbiology 127, 11-16.

Mizoguchi, J., Saito, K., Mizuno, K. \& Hayano, K. (1977). On the mode of action of a new antifungal antibiotic, Aculeacin A: inhibition of cell wall synthesis in Saccharomyces cerevisiae. Journal of Antibiotics 30, 308-313.
Mizuno, K., Yagi, S., Satol, S., Takada, M., Hayashi, M., Asano, K. \& Matsuda, T. (1977). Studies on Aculeacin: isolation and characterization of Aculeacin A. Journal of Antibiotics 30, 297-302.

Molano, J., Durán, A. \& Cabib, E. (1977). A rapid and sensitive assay for chitinase using tritiated chitin. Analytical Biochemistry 83, 648-656.

Pérez, P., Varona, R., García-Acha, I. \& Durán, A. (1981). Effect of papulacandin B and aculeacin A on $\beta$-(1,3)-glucan synthase from Geotrichum lactis. FEBS Letters 129, 249-252.

Santos, T., Villanueva, J. R. \& Nombela, C. (1978). Regulation of $\beta$ - $(1,3)$-glucanase synthesis in Penicillium italicum. Journal of Bacteriology 133, 542-548.

Shematek, E. M., Braatz, J. A. \& Cabib, E. (1980). Biosynthesis of the yeast cell wall. Preparation and properties of $\beta$ - $(1,3)$-glucan synthetase. Journal of Biological Chemistry 255, 888-894.

Traxler, P., Gruner, J. \& Auden, J. A. L. (1977). Papulacandins, a new family of antibiotics with antifungal activity: fermentation, isolation, chemical and biological characterization of papulacandins $\mathbf{A}$, B, C, and E. Journal of Antibiotics 30, 289-296.

TrINCI, A. P. J. (1979). The duplication cycle and branching in fungi. In Fungal Walls and Hyphal Growth, pp. 319-358. Edited by J. H. Burnett \& A. P. J. Trinci. Cambridge: Cambridge University Press.

WILSON, R. W. (1970). Influence of cellobiose on the colonial morphology and glycosidases of several fungi. Canadian Journal of Microbiology 16, 629-634. 